\title{
THE IMPACT OF SOCIAL SUPPORT ON THE COMPETITIVENESS OF BULGARIAN APICULTER AFTER THE ACCESSION TO THE EUROPAN UNION
}

\author{
G. Aleksiev* \\ Faculty of Economics, Trakia University, Stara Zagora, Bulagria
}

\begin{abstract}
After the transformation of Bulgarian agricultural sector during the last decade of the 20th century the social support towards this important part of Bulgarian economics was all but abstinent. The accession of the country to the European Union and implementing the Common agricultural policies of the union have rapidly increased the level of support for the sector. Although scattered and uneven the social support has effected the apicultural productions as well, mainly thanks to the National program for apiculture, which is a part of a bigger union-wide support frame.

The goal of the study is to assess the impact that social support have on the levels of competitiveness of Bulgarian apiculture, based on different sizes of productions and their access to funding.

To reach this goal the study should accomplish three tasks:

- Assessing and analyzing the level of competitiveness of different sized productions in the apicultural sector

- $\quad$ Building and discussing different Policy Analysis Matrix based on the size of the production and the time period

- Offer a conclusion and recommendations for the implementation of the Common agricultural policies of the EU and the specific apiculture support frames

The apicultural sector is heavily export oriented and it's competitiveness must be maintained and improved. The level of social support plays an important part for the development of the sector and is necessary on account of it's importance and the external positive effects it creates for the agricultural sector as a whole.
\end{abstract}

Key words: apiculture, social support, competitiveness

\section{INTRODUCTION}

Competitive development of Bulgarian beekeeping is increasingly influenced by the institutional environment and implemented by the country's agricultural policy. The importance of institutional support is strengthened after the country's accession to the European Union. The development of local programs on beekeeping for a period of three years is entrusted to all member states as part of the CAP. The variety of policy measures aimed at increasing the level of institutional support for beekeeping has a positive impact on its competitiveness and efficiency. Changes in the type, volume and range of used forms of public support warranting research eight-year period be divided into two periods of four years.

\footnotetext{
*Correspondence to: Georgi Aleksiev, Faculty of Economics,, Trakia University - Stara Zagora, Studentski grad, 6000 Stara Zagora, Bulagria, 042/699411,E-mail: georgi.alexiev@gmail.com
}

The study of public impact on the competitiveness and efficiency of beekeeping in the country can be performed based on different mathematical approaches and specific models. To achieve the objective of the proposed research is used by Monk-Pearson (Monke and Pearson, 1989) matrix for analysis of policies (MAP). The various elements of the model allow to analyze both public support in the sector and levels of efficiency and competitiveness.

\section{MATRIX FOR ANALYSIS OF POLICIES}

Using methods for determining the actual achieved competitiveness and production efficiency can only partly help in the analysis of competitive ability of a product, product group or an industry in the present or the future. The problem is compounded for changes in policy towards this sector or production and even relatively small changes occurring in the current economic model. Significant changes in ongoing agricultural 
policies in industrialized economies and the successive reforms of the Common Agricultural Policy of the European Union, questioned the universal applicability of methods for evaluating the achieved competitiveness and efficiency. In these new conditions, changes in the policies and expanding globalization, the growing importance of methods for assessing the potential competitive ability and efficiency of individual proceedings. They allow to analyze the expected results of the implementation of specific policy measures and assess their impact on the competitive ability of individual industries and sectors.

Matrix analysis of policies (MAP) is a computerized framework developed and proposed by Monk Piarsan (Monke and Pearson, 1989) and further developed and refined for the modern analysis in a highly distorted prices A. Masters and Uynter-Nelson (Masters and Winter-Nelson, 1995). It is used for measuring and evaluating efficiency in the use of resources in production and research of comparative advantages and the level of government interventions (Nelson and Panggabeen, 1991). Matrix allows to calculate the main indicators for analysis of dynamics and factor determination of the production and marketing of one or a group of products, such as: (a) the equivalent of production subsidies (Producer's Subsidy Equivalent - PSE), (b) the net social gain (Net Social Profit - NSP), (c) the ratio of social costs and benefits (Social Cost Benefit - SCB) and (d) internal costs of resources (Domestic Resource Cost - DRC). Its use in the study of the competitiveness and efficiency of individual industries and sectors allows to assess certain basic economic and social relationships such as:

- The impact of the policies pursued by the government have a comparative advantage on the level of profit level beekeeping farm.

- Impact of investment policy on economic efficiency and comparative advantages.

- The findings of the policy measures in the agricultural sector and their impact on technological development of production.
Matrix analysis of policies jointly used two types of budgets - first, based on existing market prices and second, expressed through the calculated social prices. The basic format of the matrix of policy analysis is a table with double booked systems of values, one system determines the level of profitability, and the other defines the differences between private and public values in a commodity system.

The analysis and assessment of the competitiveness of Bulgarian honey in international markets in an increasingly dynamic trade requires more potential comparability of parameters. For this purpose, the matrix for the analysis of policies is designed per unit of marketed production. Export nature and specifics of the Bulgarian Apiculture determine performance in MAP values calculated per tonne of honey. The data are based on incurred by the department of Agrostatistics MZH research and proposed by FAO information on international trade flows. Botht tables present MAP constructed for one ton of marketed honey in both parts of the studied period - the first 2007-2010 and second 2011-2014. Revenue from the sale of one ton of honey are higher in social prices due to the strong influence of the pricing policy of processing plants in the sector. Lack of cooperation in the implementation of production adversely affect the market price. The social cost per ton of honey is $7.5 \%$ higher than the market price, which is determined by the lack of public support for maintaining certain price levels of bee products.

The cost of factors of production are traded with 121.28 lev lower, due mostly public support in supplying manufacturers with tools for the treatment of bee colonies supporting "best practices" and provide a high level of safety and quality products. The purpose of the support of this Programs measure is used to modernize the sector manufacturing practices and move to safe medicines. Achieved lower costs incurred for traded inputs used as an important economic incentive for producers.

Table 1. Matrix for analysis of policies for one ton of honney $2007-2010(l v$.

\begin{tabular}{|l|c|c|c|c|}
\hline \multirow{2}{*}{\multicolumn{1}{c}{ Elements }} & \multirow{2}{*}{ Revenue } & Traded factors & Internal factors & \multirow{2}{*}{ Profit } \\
\cline { 3 - 4 } & & & 2881,56 & $-643,50$ \\
\hline Market price & 4300,71 & 2062,65 & 2926,24 & $-457,39$ \\
\hline Social Price & 4652,78 & 2183,92 & $-44,68$ & $-186,11$ \\
\hline Transfer & $-352,07$ & $-121,28$ & & \\
\hline
\end{tabular}

Source: Calculated based on data from MZH and FAO; 
Public support for lowering made the sector the average cost of domestic factors of production is minimal and its value is equivalent to only $1.5 \%$ of them. Support based unit of arable land does not affect the sector, owing to the small volume of this resource that beekeeping used in comparison with all other sub-sectors. Subsidizing entrepreneurial income in the sector or price support are possible channels of public support that will affect the economic performance of manufacturing sector. This kind of support is rejected at this time of the state policy in the agrarian sector due to the negative externalities it creates in the sector as a whole.

During the period Bulgarian beekeeping marked losses in the realization of honey produced at the rate of $15 \%$ at market prices and almost $10 \%$ social. The significant difference is due to higher by $7.5 \%$ social costs of honey. Because of the fragmented nature of the sector the bulk of the losses are distributed among small producers who fail to recover the costs incurred by internal factors. This inevitably leads to the cessation of production in these holdings after the full depreciation of used machinery and equipment. As a result of this natural process is expected to positively impact on the concentration of production in the sector.

In the second period under consideration revenue from the sale of one ton of honey increased by $9 \%$ at market prices and $7 \%$ social. This fact is due to the gradual increase in the price of honey in the domestic and international markets. The increasing role of the increasing number of large producers favor increasing purchase prices of bee products in the country. During this period under overcame initial drop in exports caused by the increased market requirements for safety and quality of honey and therefore the need to introduce adequate production practices and technologies. Increased availability of new drugs and equipment at the levels of the demand inevitably leads to lower prices. This translates into a $20 \%$ decrease in the market prices of traded inputs. The sharp decline in their prices indicates unrealistic inflated values during the first period under consideration.

Table 2. Matrix for analysis of policies for one ton of honey $2011-2014$ (lv.)

\begin{tabular}{|l|r|r|r|r|}
\hline \multirow{2}{*}{ Elements } & \multirow{2}{*}{ Revenue } & \multicolumn{2}{|c|}{ Production costs } & \multicolumn{2}{|c|}{ Profit } \\
\cline { 3 - 5 } & & & \\
& & Traded factors & Internal factors & \\
& & & & \\
\hline Market prices & 4678,98 & 1657,63 & 2711,86 & 309,49 \\
\hline Social prices & 4983,84 & 2021,19 & 2983,05 & $-20,40$ \\
\hline Transfers & $-304,85$ & $-363,56$ & $-271,19$ & 329,89 \\
\hline
\end{tabular}

Source: Own calculations based on data from MZH and FAO;

The process of concentration of production and the expansion of professional attitude towards him, started after the country's accession to the EU promotes increased efficiency in the use of domestic inputs. In the second period under consideration revenue by nearly $6 \%$ smaller in market prices compared with the first. Increasing funding to the program in beekeeping and targeted promotion of the modernization of the sector led to a reduction by $14 \%$ of costs incurred for internal production factors at social prices. Increase public support in the second period led to improved economic performance, as the absolute amount of profit amounted to 309.49 lv. average per ton of honey.

Under the influence of the expanding levels of subsidy were reached significantly higher growth rates of social prices. In the second period in they increased by $437.56 \mathrm{lv}$. average per ton of honey. Increasing revenue and reducing costs are influenced by changes in the market environment and the ongoing support of the subsector. The significant difference between general market and social prices is influenced by increasing competition which our manufacturers face on international markets.

\section{ANALYSYS OF SOCIAL SUPPORT AND MARKET TRANSFORMATION}

Matrices for analysis of policies can be used to calculate a series of indicators defining levels of comparative advantage, competitive abilities and potential impact on the effectiveness of specialization and concentration of production. Based on individual elements of the MAP is 
calculated odds and separate indicators that reflect the impact of public support on the development of the sub sector. The analysis and evaluation of opportunities to improve production potential and competitive ability, as a prerequisite for improving the processes of specialization and concentration prominently tracking the level of efficiency.

Through applications indicator Nominal Protection Coefficient on Output - NPCO expresses the extent to which domestic prices of the product differ from the established international prices. Research period noted a small increase in the values calculated for this factor, but it remains at a level lower than the unit. This means that manufacturers are not protected from the ongoing government policy measures. However, it should be noted progress made by the steps taken by the State to raise the level of public support. Although placed under 1 coefficient values are borderline, which means that while maintaining the current course of action by the government, its policies will fail to protect local producers. Developed a new program on beekeeping for three years - 2014 - 2017 was a pronounced increase in financial resources divisions, which further creates favorable conditions for the competitive development of the sector.
Nominal Protection Coefficient on Input NPCI reflects the extent to which domestic prices of traded inputs lagging behind their social prices. The values computed for this coefficient in all the period studied were lower than one and express the costs of production factors traded in the country, which are lower in comparison with their global prices. Lowering the estimated coefficient value in the period after 2010 due to increased government support to the sector. Promoting the use of EUapproved drugs and their growing subsidies have a significant impact on the average price of traded inputs.

The indicator - Effective Protection Coefficient - EPC expresses the relationship between the relative size of the added value to the individual price godfather terms of added value to the price. The transition of values in the small unit to unit transfers over such factor over the period shows changes in public support to beekeeping. The complex of administrative and economic measures limiting the development of production factor is gradually becoming favorable for its competitive and efficient development. Essential role in this process has promoted the modernization of farms and the concentration of production in the sector, leading to increasing both income and production efficiency.

Impact of public support on competitiveness (2007-2012)

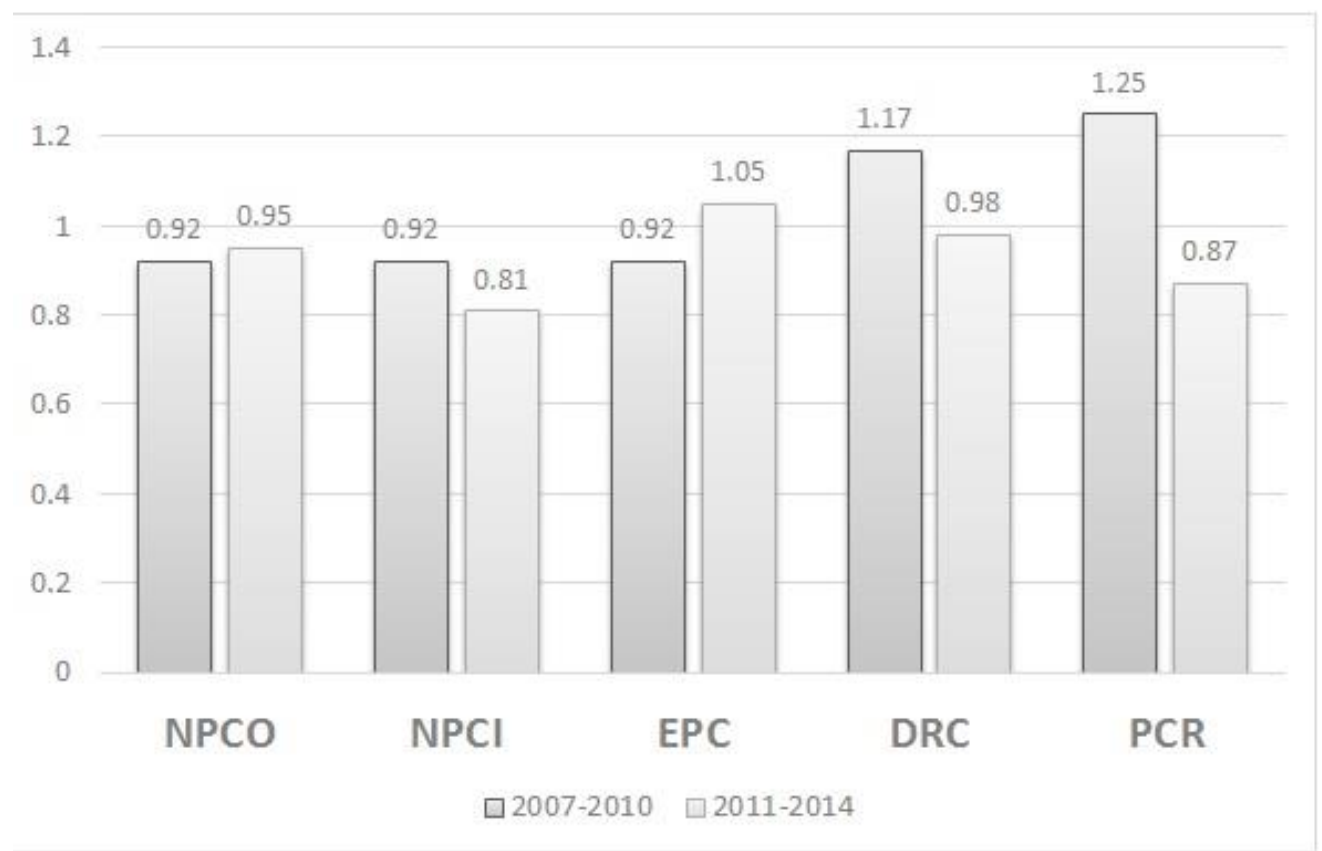

Source: Own calculations based on data from MZH;

Graphic 1. 
Based on the ratio of the cost of internal resources (Domestic Resource Cost Ratio DRC), according to its creator Bruno (Bruno, 1972) can assess the comparative advantages of individual industries and sectors. One of the widely used methods to calculate the economic efficiency of the use of internal resources in a production system is precisely this indicator. Using this method of economic analysis allows to evaluate how reducing the cost of internal resources (DRC) affects the growth of social profit. The observed decline in the coefficient during the period is mainly due to increasing share of traded inputs. Public support in the apiculture program is accompanied by increasing demands on the quality and safety of bee products, which require a change in origin and types used in production factors. This causes an increase in the share of trading factors at the expense of domestic ones.

Using the index coefficient of individual costs (Private Cost Ratio - PCR) allows to present the costs of internal factors to value added in the production system. It measures the competitiveness of the agricultural system at farm level or individual producer. In the first period under consideration the value of the coefficient is 1.29, which is lower competitiveness of the subsector. In the second half, thanks both to the improvement of the institutional environment and the increasing concentration and professionalism in beekeeping coefficient acquires values of 0.90 and is higher its competitive capabilities. Increasing value added system significantly outpaced the growth rate of the price used in the production of internal factors.

In conclusion, it can be concluded that during the period is reported to improve the institutional environment that ensures a competitive and efficient development of Bulgarian beekeeping. An increasing share of traded inputs have a negative impact, it is expected to reduce its overall impact on the sector by streamlining the channels of trade in factors of production in the country.

\section{CONCLUSION}

During the research period we take into account the improvement of the institutional environment that ensures a competitive and efficient development of Bulgarian beekeeping. The increasing share of traded inputs have a negative impact, but it is expected to reduce its overall impact on the sector in time by streamlining the channels of trade in factors of production in the country.

The main conclusion that can be drown from the study are:

- Increasing the value added in the system significantly outpaced the growth rate of the price used in the production of internal factors.

- Increasing the share of trading factors at the expense of domestic ones.

- The complex of administrative and economic measures by limiting the development of production

The impact of public support on the level of production efficiency and competitiveness of bee products is assessed with the help of matrix analysis of policies. The results show the growing role of subsidies to increase economic efficiency and competitiveness of the Bulgarian beekeeping factor is gradually becoming favorable for its competitive and efficient development.

\section{REFERENCES}

1. Porter, M.E., Competitive Advantage of Nations, N.Y., 1991, p.31;

2. Vollrath, T.L. (1987): Revealed Competitive Advantage for Wheat.Economic Research Service Staff Report No. AGES861030 (US Department of Agriculture: Washington DC);

3. Murths, T.P. et al (1998) "Country Capabilities and the Strategic State: How National Political Institutions Affect MNC Strategies", Strategic Management Journal, 15, pp 113-129;

4. FAO, (2011), "The State of Agricultural Commodity Markets", Rome, Italy;

5. MZH - Agrostatistics 